Diterbitkan oleh Program Studi Ilmu Komunikasi

Universitas Ahmad Dahlan Yogyakarta

\title{
WACANA SEKS "JALAN TENGAH” ALA MAJALAH HAI (ANALISIS WACANA KRITIS SEKSUALITAS REMAJA LAKI-LAKI DALAM ARTIKEL DAN RUBRIK SEKSUALITAS MAJALAH HAI TAHUN 1995-2004)
}

\author{
Oleh: Muria Endah Sokowati \\ Mahasiswa Doktoral Kajian Budaya dan Media UGM, \\ E-mail:muriaendah@yahoo.com \\ Oleh: PM. Laksono dan Wening Udasmoro \\ Dosen FIB/KBM UGM Yogyakarta
}

\begin{abstract}
Intisari
Seksualitas adalah entitas yang cair dan didefinisikan berdasarkan periode sejarah, ruang dan waktu tertentu.Sebagai wacana, definisi seks ditentukan oleh relasi kuasa dan pengetahuan. Penelitian ini mengungkap bagaimana seksualitas dipahami dan dikonstruksi di Indonesia lewat dua rezim yang berbeda, yaitu Orde Baru dan pasca Orde Baru.Kedua rezim yang dikuasai oleh kelompok berbeda dengan konteks sosial, politik, dan budaya yang berbeda melahirkan wacana seks yang juga berbeda.Majalah Hai yang hadir selama lebih dari tiga dasawarsa menjadi objek penelitian yang relevan untuk memahami bagaimana seksualitas menjadi arena praktik kuasa dan pengetahuan.Sebagai majalah remaja laki-laki, maka seksualitas dalam penelitian ini memfokuskan pada seksualitas remaja laki-laki.Artikel dan rubrik seksualitas yang terbit pada tahun 1995-2004 dipilih sebagai kumpulan teks yang dianalisis dengan menggunakan metode Analisis Wacana Kritis yang dijelaskan oleh Norman Fairclough.Lewat analisis teks, praktik diskursif dan praktik sosial, penelitian ini menjelaskan bahwa terjadi dualitas wacana seksualitas dalam majalah Hai.Artinya wacana seksualitas remaja laki-laki yang diproduksi oleh majalah Hai merupakan kompromi atas wacana konservatisme dan liberalisme seksual.
\end{abstract}

Kata kunci: Seksualitas, Wacana, Remaja

\begin{abstract}
Abstact
Sexuality is a fluid entity and defined by the certain historical period, space and time. As a discourse, the power/knowledge relations determine the definition of sex. This research has revealed on how the sexuality is understood and constructed in Indonesian context by the different regimes: New Order and Post New Order. Both regimes were controlled by the different groups, in the different political, social and cultural contexts, and resulted the different discourses of sex. Hai magazines, which published its contents in more than three decades becomes the relevant object of this research to understand sexuality as the arena of power/knowledge practice. As the only boy magazine in Indonesia, sexuality in this research focused on boy sexuality. This research-used
\end{abstract}


Norman Fairclough's Critical Discourse Analysis-also focused on the articles and rubrics of sexuality, which published during 1995-2004 as the analysed texts. From the analysis of text, discursive and social practice, this research explained that Hai constructed the duality discourse of sexuality. It means that the discourse of boy sexuality produced in Hai magazine become the compromise of the sexual conservatism and sexual liberalism.

Keyword: Sexuality, Discourse, Adolescence

\section{A. PENDAHULUAN}

Terbit pertama kali pada 5 Januari 1977, hingga kini Hai tetap eksis dalam industri majalah di Indonesia. Dengan menyasar segmen remaja, Hai menawarkan gaya hidup khas remaja. Hai menjadi produk unik karena satu-satunya majalah bersegmen remaja laki-laki. Sebagai majalah untuk remaja laki-laki, Hai memiliki gambaran dan definisi remaja lakilaki.Majalah Hai memiliki peran yang cukup besar dalam menawarkan bentuk-bentuk maskulinitas remaja di artikel-artikelnya.

Untuk itu, Hai merupakan sarana yang tepat untuk melihat bagaimana wacana tentang maskulinitas remaja mengingat Hai merupakan cultural product dan cultural text yang sangat penting. Sebagai sebuah teks, majalah merupakan sumber referensi bagi struktur, relasi dan proses sosial (Fairclough, 1995:208). Hai merepresentasikan konsep tentang laki-laki (remaja), relasi laki-laki dengan perempuan atau laki-laki lain, dan bagaimana maskulinitas dipahami sebagai bagian dari budaya yang selalu berproses secara dinamis.Untuk memahami maskulinitas dalam majalah Hai sebagai cultural text tidak mungkin dilepaskan dari konteks sosial, politik dan budaya.

Persoalan maskulinitas sering dikaitkan dengan perkembangan seksual yang terjadi pada laki-laki. Seksualitas, bukan hanya persoalan erotisme, namun merujuk pada seluruh aspek kehidupan dan keberadaan manusia yang bersifat erotis seperti hasrat, praktik, hubungan dan identitas (Jackson, 2006). Dalam konteks maskulinitas, seksualitas mendiskusikan relasi antara laki-laki dan perempuan. Seksualitas laki-laki menjelaskan bagaimana praktik dari relasi tersebut.

Wacana seksualitas remaja laki-laki mengalami pergeseran yang dinamis dalam majalah Hai.Perilaku seksual mengalami perubahan yang disebabkan oleh semakin terbukanya informasi tentang seks, perubahan peran gender, dan semakin diterimanya tujuan seks untuk tujuan rekreasi (Negara, 2005:9).

Pergeseran wacana seksualitas laki-laki yang dibangun oleh majalah Hai berelasi dengan konteks sosial, politik, dan ekonomi di Indonesia pada tahun 1990an dan 2000an, yaitu runtuhnya kekuasaan yang telah berkuasa selama 32 tahun. Pergantian rezim pemerintahan bukan semata-mata persoalan politik, namun juga persoalan-persoalan lain. Transisi rezim juga berimplikasi pada berubahnya ideologi, termasuk ideologi gender. Atas alasan itulah, maka penelitian ini juga memfokuskan pada majalah Hai edisi tahun 1995-2004 sebagai periode transisi dari rezim Orde Baru dan pasca Orde Baru.

Majalah Hai sebagai sebuah produk sejarah yang hadir selama empat dekade tidak lepas dari pengaruh ideologi gender yang selalu berubah. Ideologi maskulin melihat bagaimana posisi laki-laki dalam struktur, relasi dan posisi sosial yang dinamis akan mempengaruhi kerja redaksi majalah Hai yang tercermin dalam produksi teks-teksnya tentang seksua- 
Diterbitkan oleh Program Studi IImu Komunikasi

Universitas Ahmad Dahlan Yogyakarta

litas. Dengan kata lain, perubahan rezim Orde Baru ke periode yang terbuka dan demokratis berperan dalam perubahan wacana maskulinitas, dalam hal ini adalah pada diskusi tentang seksualitas yang dikonstruksi secara diskursif di dalam teks majalah Hai. Berdasarkan pemahaman tersebut, maka penelitian ini menganalisis bagaimanakah wacana seksualitas laki-laki remaja yang diproduksi oleh majalah Hai pada periode Orde Baru dan pasca Orde Baru.

\section{B. LANDASAN TEORI DAN METODE PENELITIAN}

\section{Konstruksi Sosial Atas Seksualitas Dan Maskulinitas}

Maskulinitas sering dikaitkan dengan perkembangan seksual laki-laki.Seksualitas merupakan relasi laki-laki terhadap perempuan.Relasi tersebut tidak hanya terbatas pada hal-hal yang bersifat fisik, namun juga merupakan sebuah tindakan yang melibatkan kesenangan, sensasi, keintiman, rasa cinta, saling menjaga dan ketergantungan (Sprecher dan McKinney dalam Pearson, West dan Turner, 1995:8). Sebagai tindakan yang melibatkan relasi antar jenis kelamin, seksualitas mengatur peran seksual antara laki-laki dan perempuan.

Seperti maskulinitas, seksualitas merupakan konstruksi sosial. Seksualitas bukan semata-mata dorongan biologis, namun lebih ditentukan oleh proses sosialisasi yang spesifik pada waktu dan kultur tertentu (Kimmel, 2005:141). Akibatnya seksualitas menjadi cair yang selalu berubah dari satu waktu ke waktu yang lain.

Sebagai sebuah konstruksi sosial, seksualitas ditentukan oleh gender.Bagi laki-laki, konsep maskulinitas, definisi budaya atas manhood menentukan konstruksi seksualitas. Lewat pemahaman maskulinitas, seksualitas dikonstruksi, dan selanjutnya melalui seksualitas identitas gender seseorang akan dikonfirmasi. Gender menginformasi seksualitas dan seksualitas menginformasikan gender.

Sebagai konstruksi, seksualitas dibentuk dan diproduksi di dalam wacana. Persoalan relasi kekuasaan terjadi saat wacana dibentuk (Foucault dalam Hall, 1997: 44). Adanya dominasi dan kontrol menyebabkan tidak ada definisi tetap untuk menjawab apa dan bagaimana seksualitas. Wacana tidak pernah stabil dan bersifat situasional.Penjelasan di atas menggarisbawahi bahwa wacana seksualitas dibentuk lewat seperangkat aturan yang menentukan praktik wacana tersebut. Pada titik inilah wacana tentang seksualitas tidak terlepas dari sistem yang menempatkan apa saja yang dianggap patut dan tidak patut, benar dan salah, normal atau menyimpang yang didefinisikan lewat makna-makna yang beroperasi dalam wacana tersebut.

Wacana seksualitas beroperasi dalam sistem norma heteroseksual. Norma heteroseksual mengklasifikasikan laki-laki dan perempuan dalam relasi tertentu yang secara tegas dibedakan oleh kultur patriarki. Norma heteroseksual sebagai norma yang mengatur hubungan seksual yang melibatkan jenis kelamin yang berbeda, yaitu laki-laki dan perempuan telah menempatkan maskulinitas identik dengan kekuasaan.

Beroperasinya rezim wacana atas seksualitas memunculkan apa yang disebut oleh Ken Plummer (2005) sebagai hegemonic male sexuality. Apa dan bagaimana laki-laki ditentukan oleh penis baik secara fisik maupun simbolis.Penis bukan semata-mata ciri biologis laki-laki, namun merupakan simbol atas kekuatan dan dominasi laki-laki.Beberapa 
persoalan yang ditimbulkan oleh penis, seperti ukuran atau kemampuan dan ketahanan untuk ereksi menjadi standar seksualitas laki-laki.

Berdasarkan pandangan hegemonik, laki-laki adalah aktif secara seksual.Sistem patriarki yang melegalkan praktik dominasi laki-laki atas perempuan mengakibatkan relasi yang timpang, termasuk adanya perbedaan peran seksual yang tidak setara.Laki-laki secara seksual memiliki peran sebagai pelaku (doer) sementara perempuan berperan sebagai gatekeeper.Ketidaksetaraan peran seksual tersebut menghasilkan konstruksi bahwa lakilaki lebih seksual daripada perempuan.Laki-laki selalu berupaya meningkatkan perilaku seksualnya untuk menunjukkan kelaki-lakiannya, sementara perempuan harus mengontrol perasaan seksualnya jika tidak ingin dianggap hina (Kimmel, 2005:5).Konstruksi laki-laki yang aktif membenarkan perilaku laki-laki sebagai sexual consumer dari semua aktivitas seks, mulai dari pornografi, striptease, prostitusi dan sebagainya. (Plummer, 2005:179).

\section{Analisis Wacana Kritis Sebagai Pisau Analisis}

Penelitian ini menggunakan metode analisis wacana kritis sebagai pisau analisis. Analisis teks dilakukan pada artikel dan rubrik seksualitas majalah Hai yang terbit pada periode Orde Baru dan pasca Orde Baru untuk melihat wacana seksualitas remaja laki-laki. Fairclough (2000) menyebut wacana meliputi penggunaan bahasa dalam bentuk tulisan dan verbal, juga aktivitas semiotik, yang meliputi citra visual dan bentuk-bentuk komunikasi nonverbal. Ia mengemukakan tiga dimensi analisis: teks, sebagai rekaman peristiwa dan berfungsi mengkomunikasikan fakta tertentu; praktik diskursif, tentang proses produksi dan konsumsi teks; dan praktik sosiokultural yang melihat teks sebagai bagian dari praktik sosial dan budaya tertentu.

Penelitian ini melihat bagaimana seksualitas laki-laki dipahami dan dipraktikkan dalam konteks budaya dan masyarakat yang dipengaruhi sistem sosial, politik, dan budaya yang berlaku pada periode tertentu. Wacana seksualitas laki-laki adalah teks yang berkaitan dengan praktik diskursif, dalam hal ini bagaimana pemahaman ideologi gender redaksi majalah Hai; dan praktik sosiokultural, yaitu konteks sosial, politik, dan budaya pada saat artikel-artikel tersebut diproduksi.

Sumber data penelitian ini adalah artikel dan rubrik seksualitas majalah Hai yang terbit tahun 1995-2004 sebagai periode transisi Orde Baru ke pasca Orde Baru, sehingga dapat menggambarkan dinamika wacana seksualitas remaja laki-laki di periode yang berbeda. Topik-topik yang diteliti meliputi seks, identitas dan peran gender, orientasi seksual, erotisisme, kenikmatan, kemesraan, dan reproduksi.

\section{PEMBAHASAN}

\section{Dualitas Wacana Seksualitas Remaja Laki-Laki}

Tema-tema seks dalam majalah Hai berfungsi sebagai pendidikan seks bagi remaja. Sauerteig dan Davidson (2009:1) menjelaskan bahwa pendidikan seks menjadi sarana berlakunya konstruksi sosial atas apa yang dipahami dan diberlakukan oleh masyarakat tentang seksualitas yang normal. Untuk itu, pendidikan seks menjadi sebuah situs berlangsungnya pertarungan kepentingan politis antara orang tua, guru, manajemen sekolah, pem- 
Diterbitkan oleh Program Studi Ilmu Komunikasi

Universitas Ahmad Dahlan Yogyakarta

buat kebijakan, juga institusi-institusi lain. Dalam pendidikan seks tidak ada konsensus yang mampu mengakomodasi kepentingan kelompok-kelompok tersebut (Kirby dan Michaelson dalam Allen, 2011).

Keragaman wacana dalam pendidikan seks yang diteliti oleh Holzner dan Oetomo (2004) menunjukkan adanya dua titik ekstrim wacana seks dalam pesan-pesan pendidikan seks untuk remaja, yaitu wacana yang mengadopsi pemahaman seksualitas normatif dan wacana yang mengadopsi ide tentang kenikmatan seksual.Lalu bagaimana wacanaseks dalam artikel dan rubrik pendidikan seks dalam majalahHai?Hai tidak melarang ataupun permisif terhadap seks. Wacana yang dibangun oleh Hai merupakan negosiasi Hai atas wacana seksualitasnormatif dan konservatif dan wacana kebebasan seksual. Wacana seks "jalan tengah" sebagai bentuk negosiasi tersebut diidentifikasi lewat dua wacana tentang seks berikut:

\section{Seks: Tabu Tapi Perlu}

Pada penerbitan di akhir periode Orde BaruHai menganggap seksualitas dan seks sebagai tema yang sensitif dan kerap berujung pada polemik yang diekspresikan lewat tulisan dalam artikel "Heboh Penelitian Seks Remaja" (14/9/1995) berikut:

Penelitian perilaku seks remaja sering banget dibuat orang.Dan selalu bikin heboh. Kok, nggak bosan, ya?

Membicarakan soal seks rupanya masih merupakan hal yang tabu sampai sekarang. Apalagi kalau menyangkut remaja.

Dalam penelitian perilaku seks, bukan remaja saja yang bikin panik orang lain. Peneliti dan instansi akademik pun kena, jreng!

Hai membahas pro dan kontra penelitian tentang perilaku seksual remaja. Frame yang dibangunadalah penelitian seks selalu kontroversial. Hai berposisi pada pentingnya penelitian seks dilakukan, seperti pada artikel bertema serupa berjudul "Seksualitas Remaja: Mencari Tapal Batas" (15/10/1996) yang terbit setahun kemudian.

Sayangnya, tiap kali ada penelitian, yang muncul justru heboh. Sang peneliti "kena kemplang" sana sini.

Takut kena 'kemplang' dan dipersalahkan kurang bermoral. Itulah: seks masih dipandang lebih pada tabunya.

Dari dua tulisan bertopik sama di tahun yang berbeda tidak memperlihatkan $\mathrm{Hai}$ mengikuti arus pemahaman dominan yang meniadakan diskusi seks bagi remaja. Justru Hai menganggap seks penting bagi remaja.Keberpihakan Hai pada seks ditunjukkan pada pernyataan bahwa seks bukan sesuatu yang negatif. Dalam artikel "BF Itu Bukan Pendidikan Seks" (15/10/1996), dijelaskan bahwa istilah "seksadalah istilah netral. Namun "kita" (merujuk pada Hai dan pembaca) mengartikannya jelek.

Dalam kerangka seksualitas normatif, ada upaya melakukan represi terhadap seksualitas yang menyebabkan seks menjadi tabu untuk dibahas.Kaum remaja yang dikategorikan sebagai individu yang belum dewasa dianggap belum pantas untuk membahas 
persoalan seks.Seks cenderung ditutup-tutupi.Namun Hai mempunyai pemahaman yang berbeda. Remaja berusaha menemukan identitas dan mendefinisikan konsep diri, sehingga menjadi sosok yang memiliki rasa ingin tahu yang besar.Remaja memerlukan informasi yang menjadi sumber referensi untuk menemukan jati dirinya, termasuk informasi tentang seks.Atas dasar itu pula Hai menganggap remaja sebagai objek yang perlu diberi informasi tentang seks yang dianggap benar sehingga tidak terjebak pada perilaku seks yang tidak sepantasnya.

Mendiskusikan seks secara terbuka masih terkendala oleh pandangan seks sebagai hal tabu.Untuk itu Hai melihat pendidikan seks perlu diselenggarakan di sekolah-sekolah.Tulisan-tulisan tentang seks menunjukkan bagaimana Hai tidak sepenuhnya mewacanakan seks yang normatif, karena Hai tidak tunduk dengan wacana dominan yang dibangun oleh orang tua-dalam hal ini diwakili oleh guru-bahwa remaja belum pantas untuk mendiskusikan seks. Hai menjelaskan bahwa seks bukan sesuatu yang kotor, dan justru penting diketahui remaja.Wacana tersebut dibangun Hai dengan menggunakan penjelasan dokter sebagai legitimasi.

Strategi Hai untuk mendiskusikan seks lewat pendidikan seks relevan dengan apa yang disebut Foucault (1978) dalam Sejarah Seksualitas sebagai pembiakan wacana seks. Dalam tulisan tersebut, Foucault menjelaskan bahwa seks adalah strategi kekuasaan. Sejarah seksualitas menunjukkan adanya relasi antara seks dan kekuasaan.Lewat hipotesis represi, Foucault menjelaskan adanya represi terhadap wacana tentang seks.Namun, represi justru mendorong terjadinya pembiakan wacana atas seks itu sendiri. Seks justru didiskusikan dalam kerangka religius lewat ritual pengakuan dosa; persoalan demografis, yaitu problematika tentang populasi; kedokteran, dalam hal ini medis dan psikiatri; dan peradilan pidana.Untuk itu Foucault (dalam Gauntlett, 2008:110) tidak mengatakan bahwa seks benar-benar direpresi, namun merupakan obsesi sosial. Artinya adalah setiap upaya untuk merepresi seks, justru mendorong seks untuk dibicarakan dalam bentuk-bentuk lain.

Lebih lanjut Foucault (1978) menjelaskan upaya kontrol terhadap anak-anak dan kaum remaja atas seks justru melahirkan bentuk-bentuk wacana baru tentang seks. Wacanawacana seks dilegitimasi lembaga-lembaga pendidikan dengan menciptakan pedagogisasi seks anak, termasuk kaum remaja. Anak-anak dan remaja diasumsikan berpotensi melakukan praktik seksual.Praktik seksual di kalangan anak-anak dan remaja dianggap berbahaya karena dapat menimbulkan kerusakan fisik dan moral baik secara individu maupun kolektif. Pedagogisasi melibatkan orang tua, keluarga, guru, dokter dan psikolog. Lembaga pendidikan ini kemudian menetapkan standar-standar tentang apa yang boleh dan tidak boleh, yang halal dan haram; juga larangan dan ancaman bagi yang melanggar. Adanya standarstandar tersebut membuat pihak-pihak tertentu mempunyai wewenang untuk mendiskusikan seks dengan anak-anak dan remaja.Pendidikan seks menjadi sarana legitimasi atas perilaku seksual remaja.

Dalam bingkai penjelasan Foucault tersebut, artikel dan rubrik seksualitas dalam majalah Hai bisa dibaca sebagai pembiakan wacana seksualitas sebagai implikasi atas pemahaman normatif bahwa seks tidak pantas didiskusikan, terutama oleh remaja. Alasan kepentingan pendidikan seks bagi remaja sebagai tujuan pembahasan seks di artikel dan rubrik-rubriknya menjadi modus Hai untuk mendiskusikan seks dengan pembacanya. Pendidikan seks memberikan standar-standar mana yang boleh dan tidak boleh dilakukan 
Diterbitkan oleh Program Studi IImu Komunikasi

Universitas Ahmad Dahlan Yogyakarta

oleh remaja, sehingga diskusi seks tersebut merupakan sarana legitimasi Hai atas perilaku seksual remaja.Keterlibatan pihak-pihak yang dianggap pakar, seperti dokter, psikolog, dan sosiolog sebagai narasumber dan rujukan semakin menguatkan legitimasi tersebut.

Alasan perlunya pendidikan seks selalu disebut dalam tulisan-tulisannya adalah masa tunggu pacaran yang lama. Hai menyebut istilah "bisa tapi belum boleh" untuk menunjukkan bahwa remaja di masa tersebut berbeda dengan remaja pada generasi sebelumnya. Remaja masa kini dilekatkan tanggung jawab untuk meraih cita-cita setelah mereka menyelesaikan pendidikannya.

Istilah "bisa" mengindikasikan bahwa usia remaja adalah awal usia reproduktif. Di usia ini, organ-organ reproduksi sedang berkembang. Sedangkan "belum boleh" menunjukkan bahwa di usia tersebut, fungsi reproduksi remaja belum siap menjalankan fungsinya. Alasan medis yang merasionalisasi adalah karena organ-organ reproduksi usia remaja belum sempurna. Beberapa resiko medis yang ditimbulkan jika organ-organ tersebut dipaksakan untuk difungsikan adalah munculnya beberapa penyakit, seperti kanker serviks missalnya. Kehamilan di usia dini juga memiliki resiko yang cukup besar. Secara psikologis, usia remaja adalah usia di mana remaja sedang berada dalam proses pencarian jati diri. Pada usia tersebut, remaja belum siap secara mental dan psikis untuk hamil dan memiliki anak. Alasan lain yang kerap disampaikan untuk mendukung remaja "belum boleh" melakukan aktivitas seksual adalah alasan moralitas, bahwa berhubungan seks di luar ikatan pernikahan adalah tindakan yang melanggar norma dan nilai moralitas.

Berdasarkan alasan-alasan tersebut, seks tabu bagi remaja karena dikaitkan selalu dengan persoalan reproduksi. Seks adalah sarana untuk memperoleh keturunan, sehingga seks hanya dianggap wajar dan normal jika dilakukan dalam ikatan perkawinan. Untuk itu remaja harus menahan hasrat seksualnya selama "masa tunggu" tersebut. Di sinilah perlunya pendidikan seks.

Dalam penjelasan seks, Hai memberikan rujukan nilai dan norma dominan, seperti tidak berhubungan seks sebelum menikah atau bagaimana seks bertujuan untuk memperoleh keturunan. Justru atas dasar pertimbangan moralitas tersebut, maka pendidikan seks menurut Hai perlu disampaikan kepada remaja.

Selain itu Hai juga membandingkan perilaku seks remaja di Indonesia dan di negara-negara barat yang disebutkan sebagai negara penganut seks bebas. Di Indonesia seks bebas tidak dapat dilakukan oleh remaja karena bertentangan dengan nilai dan norma yang dipahami masyarakat. Hal tersebut dituliskan:

Ngomong soal gaya pacaran di sini sama di luar jelas beda. Di Inggris, Skotlandia dan Wales, sex bahkan udah dinyatakan legal sejak remaja menginjak umur 16 tahun (antara cowok-cewek, dan cowok-cowok). Di Irtandia Utara, sex juga dinyatakan legal untuk remaja 17 tahun, juga antara cowok-cewek dan cowok-cowok.

Di Indonesia, bikin aturan kayak gitu jelas sebuah mission yang impossible. Gagasan baru dilontarkan aja pasti bikin ortu kita empot-empotan.Bahkan mungkin juga menimbulkan kehebohan di seantero negeri kita tercinta ini.Orang dewasa aja kalo belum menikah harusnya nggak boleh tuh yang namanya having sex. Soalnya budaya, kebiasaan, dan norma-norma yang dianut di sini masih begitu ketat(3/3/2003). 
Bagi Hai, seks perlu didiskusikan lewat pendidikan seks. Diskusi seks dalam pendidikan seks terikat oleh nilai-nilai dan norma-norma tentang apa yang boleh dan tidak boleh. Ada standar-standar yang digunakan pihak yang kompeten, seperti rohaniwan, dokter, psikolog, dan pendidik. Merekalah yang membuat legitimasi atas seks yang baik, normal, tabu atau dilarang.

Wacana seks sebagai hal yang tabu tapi perlu mengindikasikan bahwa Hai tidak menolak pemahaman tentang seks yang tabu bagi remaja.Namun, remaja yang dianggap sebagai kategori sosial yang problematis perlu mendapat informasi tentang seks untuk menjauhkan mereka dari akibat buruk dari seks. Hai seolah-olah membebaskan remaja dari pemahaman seksualitas yang konservatif, namun justru kembali lagi pada pemahaman yang normatif ketika Hai merujuk pada norma dominan dalam menjustifikasi seks yang normal dan yang tidak normal.

\section{Seks adalah Pilihan (Yang Dipilihkan)}

Secara tersurat, Hai menyatakan bahwa seks adalah pilihan.Kalimat tersebut banyak ditemukan dalam artikel maupun rubrik seksualitas.Sebagai implementasi pernyataan bahwa seks adalah pilihan, Hai melengkapi informasinya dengan berbagai konsekuensi atas pilihan-pilihan tersebut. Dalam artikel "Jangan "Begituan" Sebelum Nikah" (26/2/1999), Hai menghimbau tidak melakukan hubungan seksual selain dengan isteri/suami dengan alasan berhubungan seksual tanpa komitmen mendorong untuk berganti pasangan dan beresiko menularkan HIV/AIDS dan penyakit menular seksual lain, kehamilan yang tidak diinginkan, aborsi, dan persoalan psikis. Istilah "jangan" lebih tepat untuk menjelaskan sesuatu yang hendaknya tidak usah dilakukan. "Jangan" bukan larangan, tapi himbauan.

Contoh lain terdapat dalam artikel tentang kondom. Pembahasan kondom selalu menjadi pro dan kontra di antara fungsinya untuk mencegah penularan penyakit AIDS yang jumlah penderitanya semakin mengkhawatirkan dan mencegah kehamilan.Fungsi terakhir sering disalahgunakan menjadi "alat pengaman" perilaku seks bebas.Akibatnya kondom dianggap sebagai sarana seks bebas sehingga ditentang kalangan agamis dan masyarakat yang memegang nilai-nilai tradisional.

Hai menjelaskan kondom dari sudut pandang preventif.Hai menganalogikan kondom sebagai "sarung pengaman", yang mengamankan pasangan dari resiko penularan HIV, penyakit menular seksual lain, kehamilan tak diinginkan dan aborsi. Namun, Hai menyadari resiko membuka wacana pentingnya kondom di kalangan pembaca yang notabene adalah remaja. Untuk itu, Hai menjelaskan secara berulang bahwa tujuan Hai mendiskusikan kondom bukan untuk mempersilakan remaja melakukan seks bebas. Hai selalu mengingatkan pembacanya tentang resiko perilaku seks bebas.Dalam artikel "Mitos Seputar Kondom" (15/2/2001) disebutkan:

Terutama karena anjuran pakai kondom itu sama sekali bukan untuk membolehkan seks sembarangan. Karena itu nggak ada salahnya kita tau gimana sebetulnya kondom.

Pernyataan tersebut diulang lagi pada bagian akhir tulisan tersebut:

Anjuran make kondom tujuannya sama sekali bukan ngasih ijin melakukan hu- 
Diterbitkan oleh Program Studi Ilmu Komunikasi

Universitas Ahmad Dahlan Yogyakarta

bungan seksual secara bebas.

Dalam artikel "Kondom, Siapa Yang Butuh?" (6/10/2000) Hai menyampaikan perlunya remaja paham tentang kondom. Hai menulis, "Sama aja gaptek kalo nggak tau kegunaan kondom". Hai menyamakan kondom dengan teknologi yang seharusnya menjadi bagian dari gaya hidup remaja.

Bagi Hai, kondom diperlukan remaja yang sudah telanjur aktif secara seksual. Namun, agar tidak disalahartikan sebagai pendukung remaja pelaku seks bebas, Hai selalu menjelaskan bahwa remaja seharusnya tidak perlu melakukan hubungan seksual. Untuk itu, kondom menjadi satu-satunya pilihan paling aman bagi pasangan yang memilih melakukan hubungan seks di luar nikah. Kondom menjadi perlu karena pada kenyataannya banyak remaja yang tidak bisa mengerem perilaku seksnya dan berakibat pada kehamilan tidak diinginkan, aborsi, dan penularan penyakit kelamin, termasuk AIDS. Untuk mendukung pernyataannya, Hai mencantumkan data empiris tentang penularan HIV di kalangan remaja.

Tidak hanya saat membahas kondom, seks sebagai pilihan disampaikan lewat penjelasan bahwa perilaku seksual harus dilakukan dengan tanggung jawab. Misalnya dalam artikel berjudul "Ciuman Menjurus", "Ciuman yang hot susah dicopot. Biar nggak menjurus pakai otak dong” (23/7/1999). Atau artikel seks bebas berikut:

Well, jangan sekali-sekali main-main dengan proses "bikin anak" ini. Karena sekali pembuahan terjadi, bakal ada sekian proses lagi yang menunggu tanggungjawab kita (Cewek Hamil?, 26/3/1999)

Jadi, pertanyaan bisa atau nggak pacaran tanpa seks, emang nggak bisa dijawab satu atau sekali.Bisa atau nggak, kitalah yang memilih. Sebab setiap perilaku seksual punya konsekuensi sendiri-sendiri, nggak sama pada setiap orang. Ada yang menjadi tertekan, ada yang merasa berdosa, ada juga yang merasa senang dan tanpa beban (Pacaran Harus Dengan Seks?, 2/4/2001).

Tulisan ini nggak nyaranin kamu buat berseks bebas. Remaja bukan anak kecil lagi yang harus dikasih tau mana yang baik dan enggak. Tapi, segala sesuatunya harus dipikir-pikir dulu. Terutama soal niat ber-ML ria sebelum saatnya. Terbukti dari cerita di atas kebanyakan dari teman kita yang ngelakuinnya pasti merasa nggak nyaman. Berani nyoba kudu berani nggak nyaman (Di Jalan Tolpun Jadi Seks Bebas, 6/10/2000).

Hai menjelaskan bahwa tindakan seksual adalah tanggung jawab laki-laki dan perempuan.Keduanya memiliki hak yang sama menolak pacaran yang melampaui batas yang sudah disepakati. Inti pacaran sehat adalah mengkomunikasikan keinginan masing-masing (dalam artikel "Pacaran Nggak Perlu Berujung Sex"di Hai edisi 3/3/2002), termasuk bertanggung jawab menjaga keperawanan maupun keperjakaan (dalam artikel "Hilang Virgin? No Way” (6/8/1999), atau ““"Kesucian” Bukan Monopoli Perawan” (30/4/1999)).

Seks sebagai pilihan ditegaskan Hai lewat artikel tentang konsekuensi perilaku seks bebas. Hai memberikan pilihan pada pembaca untuk melakukan seks bebas atau tidak. Jika memilih melakukannya, akibat yang mungkin terjadi antara lain kehamilan tak di- 
inginkan, ataugangguan psikologis. Jika terjadi kehamilan ada beberapa opsi yang ditawarkan, yaitu meneruskan kehamilan atau aborsi.

Aborsi sering menjadi pilihan karena memudahkan laki-laki. Hai menjelaskan secara gamblang akibat aborsi, dan berposisi menolak aborsi karena resiko yang terjadi, terutama yang dialami perempuan.Sementara bagi laki-laki relatif tidak mengalami akibat apa-apa. Hai lebih menyarankan untuk meneruskan kehamilan yang resikonya juga banyak. Misalnya dalam artikel "Hamil? Oh My God" (28/1/2002), dijelaskan pengalaman tentang kehamilan yang tak diinginkan. Dalam artikel "Panik Karena Ngehamilin: Bisa Sad End Bisa Juga Happy End" (28/1/2002), Hai menjabarkan beberapa pilihan yang ditempuh remaja jika meneruskan kehamilan. Pengalaman remaja yang memilih aborsi maupun mempertahankan kehamilan sama-sama sulit, sehingga bagi Hai yang terbaik adalah menghindari perilaku seks bebas.

Akibat seks bebas lainnya adalah akibat psikologis. Bagi laki-laki merupakan beban yang berat memiliki anak di usia muda sementara secara mental belum siap.

Taruhan, pasti kamu nggak bakal mau kalo disuruh ngegendong batu bata yang tiap bulan ditambahsatu selama sembilan bulan sepuluh hari penuh. Kamu nggak bakal bisamain skateboard, ber-pogo ria, susah buat jalan jalan (Kisah Mereka Yang “Kecelakaan”: Maju Kena Mundur Kena, 10/3/2000).

Bagi perempuan beban psikologisnya justru lebih berat, seperti dijelaskan berikut ini:

Belum lagi pandangan sinis akan mampir ke cewek. Perutnya yang tiap hari membuncit akan jadi pusat perhatian dan pusat pergunjingan yang seru. Emangnya enak digunjingin? Bisa bikin kuping panas dan hati sakit! Aborsi? Gila apa? Darah daging sendiri mau dihabisi! Susah kan pilihannya, aborsi (diluar kepentingan medis) salah, nerusin kandungan risikonya menyakitkan hati (Kisah Mereka Yang "Kecelakaan”: Maju Kena Mundur Kena, 10/3/2000).

Akibat lain adalah resiko terkena penyakit menular seksual dari sifilis hingga AIDS

Untuk membantu remaja menentukan pilihan mereka, Hai memberikan panduan bagi remaja, Panduan tersebut menjadi sebagai patokan apakah pembaca sudah siap dengan hubungan seks dengan memberikan kuis tentang kesiapan remaja untuk melakukan seks bebas. Untuk pembaca yang ternyata siap, Hai mempersilakan mereka untuk menjalaninya:

Eit, dahsyat man! Mental kamu siap banget. Meskipun tau risiko yang bakal dihadapi sejembreng, tapi niat nyobain seks di usia dini udah terpancang kokoh. Sebelum "nyemplung" kamu udah mikirin tindakan apa yang bakal diambil kalo suatu saat tertimpa risiko premarital. Dari risiko cewek hamil sampe ketempelan virus penyebab penyakit yang mematikan.

Nggak cuma itu, kamu juga udah berpikir jauh soal masa depan setelah kena risiko premarital seks. Misalnya mikirin strategi untuk jadi bokap muda. Oke juga. Kalo emang udah siap ya udah jalanin aja. Toh udah nggak ada beban kan? (Are You 
Diterbitkan oleh Program Studi Ilmu Komunikasi

Universitas Ahmad Dahlan Yogyakarta

Ready To Take The Risk? 4/3/2002).

Wujud lain dari konsep seks adalah pilihan juga ditunjukkan Hai lewat perlunya remaja membuat keputusan, termasuk pilihan untuk menjalankan perilaku-perilaku seks yang dianggap menyimpang atau menghindarinya. Selama dilakukan tanpa keterpaksaan dan tahu resikonya, Hai mengatakan bahwa hal itu bukan masalah. Istilah yang sering digunakan adalah, "It's ok." Misalnya soal membuat blue film pribadi dalam artikel "Bikin Blue Film Pribadi" (29/10/2001).

Menariknya, Hai tidak mengarahkan pembaca untuk menilai perilaku itu bertentangan dengan moralitas. Alih-alih memberikan justifikasi normatif, Hai justru mendiskusikan apakah kegiatan merekam adegan intim dan privat itu normal atau tidak. Mengutip pendapat seorang psikolog, Hai menyatakan bahwa perilaku itu sah-sah saja dilakukan jika tidak disalahgunakan, hanya disimpan untuk dokumen pribadi dan tidak dipertontonkan kepada orang lain. Kegiatan itu menjadi tidak normal apabila pelaku ketagihan sehingga menjadi suatu kebiasaan.Fokus diskusi adalah pada perilaku merekamnya, bukan perilaku seksualnya.Hai juga menekankan perlunya kedewasaan dan sikap tanggungjawab pelaku, seperti tertulis berikut:

So kesimpulannya, bikin bokep pribadi buat koleksi pribadi itu adalah perilaku manusia zaman sekarang yang nggak bisa langsung dicap kelainan.Tapi ingat, tanpa sikap dewasa dan tanggung jawab, perilaku ini bakal mengundang masalah.

Kedewasaan penting banget supaya kita selalu berpikiran sehat.Terutama karena seks adalah sesuatu yang gampang dieksploitasi oleh mereka yang nggak bertanggungjawab, sekalipun dia adalah pacar atau pasangan nikah kita sendiri.

Hal yang sama berlaku saat Hai membahas seks di internet, dalam artikel "Sex di Internet: Ya Enak, Ya Bikin Eneg" (28/5/2001), Hai mendiskusikan apakah perilaku tersebut wajar atau tidak mengingat di masa itu fenomena ini relatif baru seiring dengan semakin terbukanya akses internet di kalangan masyarakat. Hai menyatakan bahwa kebiasaan ini wajar saja selama dilakukan dengan sadar dan bertanggung-jawab, atau tidak bikin ketagihan. Dalam artikel penyimpangan seksual berjudul "Senang Kalau Korbannya Ketakutan" (21/5/1999), Hai membahas bentuk-bentuk penyimpangan seperti eksibisionis, sodomi atau voyeurisme. Tidak ada himbauan untuk tidak melakukan hal tersebut. Hai menegaskan bahwa itu adalah soal pilihan seperti tertulis, "Soal pilihan, ya jawabannya ada di benak kita sendiri."

Penekanan pada tanggung jawab juga muncul dalam pembahasan tentang pornografi. Dalam artikel berjudul "Bikin Nggak Gaul" (2/3/2004) Hai menghimbau perlunya pengendalian diri agar terhindar dari godaan pornografi. Selama memiliki pengendalian diri, remaja tidak akan terjebak pada efek buruk pornografi karena-mengutip seorang psikolog-merupakan sesuatu yang normal jika manusia menyukai segala macam stimulus seksual. Hai menekankan hal tersebut pada tulisan berikut:

Lagian, hebat dong kalo kita bisa jadi cowok yang mampu berkata tidak ketika kita 
nggak mau melakukan sesuatu yang salah dan mampu jadi tuan bagi diri kita sendiri?

Dengan menyatakan seks adalah pilihan, seolah-olah Hai permisif terhadap seks bebas.Namun yang tercantum di dalam tulisan-tulisannya ternyata tidak demikian. Walaupun Hai memberikan beberapa opsi, di akhir tulisan Hai mengarahkan pada pilihan terbaik. Misalnya, dalam tema seks bebas, Hai menyampaikan kepada pembaca untuk memilih melakukan seks bebas atau menghindarinya. Dalam "Cukup Sampai Kissing Aja Lho" (3/3/2003), ditulis, "Pilihannya simple aja kok, ya atau tidak buat seks". Walaupun mempersilakan untuk melakukan seks atau tidak, opsi terbaik adalah menghindarinya. Pernyataan tersebut disampaikan dengan menyebutkan bahwa pacaran sebaiknya dipandang sebagai proses persiapan menuju pernikahan (dalam artikel "Pacaran Sehat"di Hai edisi 23/7/1999), atau menegaskan bahwa melakukan seks sebelum menikah melanggar normanorma agama (dalam artikel "Pacaran Harus Dengan Seks? Di Hai edisi 2/4/2001). Untuk menguatkan pilihan ideal tersebut, Hai membuat label-label "pacaran sehat", atau membuat kategori "seks yang aman" dan "seks yang tidak aman" (dalam "Pacaran Harus Dengan Seks?" di Hai edisi 2/4/2001).

Dari pemaparan di atas, Hai menjelaskan bahwa seks adalah pilihan yang beresiko. Dengan memahami konsekuensinya, remaja berhak membuat pilihan atas perilaku seksnya. Namun, pilihan terbaik adalah tidak melakukan seks bebas.Dengan demikian, Hai tidak sepenuhnya mewacanakan gagasan kebebasan seksual. Idiom-idiom kenikmatan seksual, seks adalah pilihan, atau penggunaan kondom untuk menghindari penyakit menular seksual memang relevan dengan gagasan kebebasan seksual. Namun, ide kebebasan seksual yang dibangun dinegosiasikan dengan moralitas, nilai dan norma. Hal tersebut ditunjukkan dalam pilihan-pilihan sikap dan tindakan untuk pembaca yang diarahkan Hai di akhir tulisantulisannya.

Berdasarkan pemaparan di atas, Hai tidak sepenuhnya mengadopsi norma dominan, namun menegosiasikannya dengan wacana tentang kebebasan seksual. Gagasan kebebasan seksual relevan dengan penjelasan Anthony Giddens tentang emansipasi seksual. Istilah emansipasi seksual diungkapkan Giddens (1992), berkaitan dengan terminologi plastic sexuality atau decentred sexuality yang membebaskan seksualitas dari reproduksi. Seksualitas plastis merupakan bentuk pluralisme seksual di mana seksualitas tidak berpatokan pada norma-norma heteroseksual yang patriakhis. Setiap pihak yang terlibat dalam relasi seksual memiliki ruang untuk memperoleh pengalaman seksual dan mengejar keintiman. Keintiman dibangun berdasarkan pada pure relationship atau hubungan yang tulus, yaitu hubungan yang membawa kepuasan bagi masing-masing pihak.

Akibatnya, seksualitas semakin jauh dari tujuan reproduksi.Giddens (1992:164) menyebutkan seksualitas merupakan medium bagi self-realization dan sarana utama untuk mengekspresikan keintiman. Seksualitas menjadi sebuah pengalaman yang memiliki arti penting bagi kehidupan seksual seseorang. Pada titik inilah seksualitas menjadi bagian refleksi diri yang kemudian menjadi sebuah pilihan gaya hidup, sama halnya saat memilih jenis makanan, fashion, atau musik tertentu.

Seperti dibahas pada bab sebelumnya, seksualitas yang berorientasi pada kenikmatan tampil dalam media massa seiring dengan euforia kebebasan pers di Indonesia. Dengan 
Diterbitkan oleh Program Studi IImu Komunikasi

Universitas Ahmad Dahlan Yogyakarta

fungsi rekreatifnya, seksualitas menjadi komoditas media massa. Media seolah-olah merayakan kebebasannya dengan turut membawa konten seksualitas kepada khalayak. Seksualitas yang sebelumnya dalam beberapa hal masih dianggap tabu, oleh media dibawa ke dalam ranah publik. Jika di akhir periode Orde Baru, seks sudah mulai muncul di media, maka di periode pasca Orde Baru, konsumsi konten seksual menjadi lebih luas. Siapapun dengan mudah dapat mengaksesnya.Kondisi ini membuat seksualitas sedikit demi sedikit kehilangan kesakralannya.

Lonjakan frekuensi artikel dan rubrik seksualitas pada tahun 1999 dan tahun-tahun berikutnya menunjukkan bahwa Hai menjadikan seksualitas sebagai bagian gaya hidup remaja. Tema seksualitas sejajar dengan hobi, musik, film, teknologi, selebritis, fashion, atau olahraga sebagaigaya hidup remaja. Gaya hidup dijelaskan Giddens (1991:81) sebagai seperangkat praktik yang dilakukan individu, bukan hanya aktivitas untuk memenuhi kebutuhan-kebutuhan yang berguna, namun juga sebagai elemen penting dalam membentuk narasi tentang identitas diri.Gaya hidup menyediakan pilihan-pilihan bagi individu untukdipilih dan diadopsi secara sadar dan menjadi bagian dari identitasnya.

Seksualitas dan identitas seksual dalam masyarakat menjadi bagian dari identitas diri (dalam Gauntlett, 2008:110).Misalnya adalah ketika seseorang lebih terbuka menunjukkan pilihan perilaku seksnya. Hal ini disebabkan karena tersedia pilihan-pilihan iamau menjadi apa. Yang menarik adalah seksualitas dan problematikanya menjadi narasi penting dalam biografi seseorang. Seksualitas menjadi tema populer yang diangkat dalam lagu, novel, cerpen, film, atau drama.

Selain terinspirasi oleh narasi-narasi seksualitas, media juga menjadi sarana informasi atas pilihan-pilihan tersebut. Media menawarkan beragam pilihan atas gaya hidup. Namun pilihan yang ditawarkan adalah pilihan yang telah diseleksi. Media menentukan jenis-jenis pilihan yang dianggap sebagai pilihan ideal. Dengan demikian walaupun banyak ditemui variasi gaya hidup, pilihan yang ditawarkan adalah pilihan yang terbatas. Pilihan atas peran-peran atau gaya hidup dalam media memang beragam, namun dengan interprettasi yang dangkal (Gauntlett, 2008:113).

Majalah Hai lewat artikel seksualitas memberikan informasi pada remaja tentang topik yang dianggap perlu diketahui remaja.Informasi mencakup pengertian, resiko, pencegahan dan solusi. Misalnya tentang seks bebas, Hai menjelaskan apa itu seks bebas, tindakan apa saja yang dikategorikan sebagai seks bebas, resiko apa yang akan dihadapi, apa yang harus dilakukan untuk menghindari seks bebas, dan solusi yang harus diambil jika seorang remaja sudah terkena resiko dari perilaku tersebut. Hai menjabarkan secara detil akibat dari perilaku tersebut, akhirnya Hai menyerahkan pembaca untuk memutuskan melakukan atau menghindarinya.

Memberikan pilihan pada pembaca menjadistrategi untuk mewacanakan seks adalah pilihan. Hai memberi ruang remaja pembacanya menjadi individu yang berefleksi, dan melakukan aktualisasi diri. Aktualisasi diri menjadi jalan menyeimbangkan kesempatan dan resiko (Giddens, 1991:78) yang dilakukan dengan melihat pengalaman masa lalu untuk menimbang-nimbang antara kesempatan dan resiko yang ada sehingga dapat menentukan langkah di masa yang akan datang. Bentuknya adalah menampilkan kisah-kisah remaja yang mengalami problem-problem seks, seperti: kisah remaja yang menanggung akibat seks bebas (dalam artikel “Are You Ready To The Take Risk?” di Hai edisi 4/2/2002); ki- 
sah laki-laki yang tertekan karena pacarnya hamil (dalam "Kisah Mereka Yang "Kecelakaan": Maju Kena Mundur Kena" di Hai edisi 10/3/2000), atau penyesalan gadis karena melakukan aborsi sehingga dihantui rasa bersalah yang berkepanjangan (dalam "Hamil? Oh My God" di Hai edisi 28/1/2002) atau "Suara Mereka Yang Jadi Korban" di Hai edisi 4/3/2002). Hai juga menampilkan testimoni pelajar tentang seks bebas dan pengalaman menghindarinya (dalam "Nge-Seks Saat Pacaran" di Hai edisi 3/5/2004). Hai menekankan perlunya bersikap rasional dalam berpacaran (dalam artikel "Pikir-Pikir Sebelum Pacaran" di Hai edisi 7/4/2000). Dengan menginformasikan resiko seks bebas, tips menghindari, berpikir untung rugi dan memberi label "hero" ketika remaja berhasil mengekang nafsunya, Hai memberikan ruang bagi pembacanya untuk melakukan aktualisasi diri tersebut.

Namun Hai menawarkan pilihan terbatas dan dikonstruksi sebagai pilihan ideal. Hai memberikan pilihan yang telah diseleksi. Pendekatan medis, psikologis, norma sosial dan agama menjadi acuan sehingga pilihan yang disodorkan pada pembaca merujuk pendekatan-pendekatan tersebut. Salah satu contoh bagaimana Hai mengarahkan pilihan pembaca adadi artikel "Caranya Belajar Seks Yang Asik" (5/4/2004). Hai meminta sejumlah lakilaki untuk menceritakan pengalamannya memperoleh informasi seks yang menyenangkan. Hai merangkumnya berikut ini:

Kesimpulannya, balik ke elo masing-masing sih. Mau belajar sex yang fun, cepet, tapi bahaya; atau belajar sex dengan cara yang lebih konservatif dan rada ngeboring-in, tapi aman? Kalo gue kayaknya lebih milih yang kedua sih. Soalnya gue nggak tahan nanggung akibatnya, jack

Perhatikan kalimat yang dicetak tebal. Hai mengarahkan pembaca pada pilihan yang ideal dan terbaik menurut Hai disertai alasan atas pilihan tersebut. Hai membangun wacana bahwa seks adalah sebuah pilihan, pilihan yang terbatas dan beresiko.

\section{SIMPULAN}

Berdasarkan pemaparan di atas maka dapat disimpulkan bahwa majalah Hai sebagai satu-satunya majalah remaja laki-laki di Indonesia membangun dualitas wacana seksualitas remaja laki-laki dalam artikel dan rubriknya yang dipublikasikan pada penerbitan antara tahun 1995-2004. Wacana seksualitas yang dibangun oleh majalah Hai merupakan wacana yang mengakomodasi wacana konservatisme dan liberalisme seksual. Walaupun menggunakan politik jalan tengah dalam mewacanakan artikelnya, Hai cenderung melanggengkan apa yang menjadi norma-norma dominan. Akomodasi atas kebebasa seksual merupakan upaya Hai untuk mengikuti tren baru mengingat paham ini relatif baru sebagai efek atas revolusi seksual global. 
Diterbitkan oleh Program Studi Ilmu Komunikasi

Universitas Ahmad Dahlan Yogyakarta

\section{DAFTAR PUSTAKA}

Allen, Louisa. 2011. Young People and Sexuality Education: Rethinking Key Debates, New York: Palgrave Macmillan

Fairclough, Norman. 2000. Critical Analysis of Media Discourse". Dalam Paul Marris dan Sue Thornham, Media Studies: A Reader, $2^{\text {nd }}$ ed. Washington Square, New York: New York University Press 1995. Media Discourse, London: Arnold

Foucault, Michel. 1978. The History of Sexuality Vol. 1, New York: Pantheon Books Gauntlett, David. 2008. Media, Gender and Identity: An Introduction, New York dan London: Routledge

Giddens, Anthony. 1991. Modernity and Self Identity: Self and Society in the Late Modern Age, California: Stanford University Press.

1992. The Transformation of Intimacy: Sexuality, Love, and Eroticism in Modern Society, California: Stanford University Press.

Hall, Stuart. 1997. "The Work Of Representation". Dalam Stuart Hall, Representation: Cultural Representations and Signifying Practices, London dan California: Sage Publication

Jackson, Stevi. 2006. Gender, Sexuality and Heterosexuality: The Complexity (and Limits) of Heteronormativity, Feminist Theory, 7(1)

Kimmel, Michael S. 2005.Gender of Desire: Essays on Male Sexuality, Albany: State University of New York Press

Negara. Made Oka. 2005. Mengurai Persoalan Kehidupan Seksual dan Reproduksi Perempuan.Jurnal Perempuan, No. 41

Oetomo, Dede dan Brigitte M Holzner. 2004. Youth, Sexuality and Sex Education Messages in Indonesia: Issues of Desire and Control, Reproductive Health Matters, $12(23)$

Pearson, Judy Cornelia, Richard L. West, dan Lynn H. Turner. 1995. Gender and Communication, USA: McGraw Hill

Plummer, Ken.2005. "Male Sexualities". DalamMichael SKimmel, Jeff Hearn, dan R. W. Connel, Handbook of Studies on Men and Masculinities, California: Sage Publications

Sauerteig, Lutz D. H. dan Roger Davidson. 2009. Shaping Sexual Knowledge: A Cultural History of Sex Education in Twentieth Century Europe, London and New York: Routledge 